ISSN 1112-9867

Available online at $\quad$ http://www.jfas.info

\title{
INFLUENCE OF HALAL CERTIFICATION ON CUSTOMERS' PURCHASE INTENTION
}

\author{
Z. Zakaria*, M. D. Abdul Majid, Z. Ahmad, Z. Jusoh, and N. Z. Zakaria \\ Faculty of Business Management, UniversitiTeknologi MARA, 23000 Dungun, Terengganu, \\ Malaysia
}

Published online: 17 October 2017

\begin{abstract}
The purpose of this study isto investigate the relationship between HALAL awareness, marketing and religiosity that are postulated to influence customers' intention to purchase HALAL certified consumer products. Customers' who visited SABASUN Hypermarket Sdn. Bhd. in Kuala Terengganu were selected as respondents. Questionnaires were used as the research instrument. The findings revealed there are positive relationship between the HALAL awareness and religiosity toward customers' intention to purchase HALAL certified consumer products. The results also demonstrated that religiosity is the most influential factors in motivating customers' to purchase HALAL certified products. For future study should consider demographic background as a moderating factor the can regulate the effect on factors influencing customers' intention to purchase Halal certified consumer products.
\end{abstract}

Keywords: religiosity; halal certified; halal; customer's intention

Author Correspondence, e-mail: hzainudd@tganu.uitm.edu.my

doi: http://dx.doi.org/10.4314/jfas.v9i5s.55 


\section{INTRODUCTION}

\subsection{Background of Study}

Malaysia is a multiracial country with many different races and religions, such as Islam, Christianity and Hinduism. The Halal requirement is an important concept among Muslims that assumes a vital role in their daily consumption. Currently, the concern for Halal is not only present among Muslims, but the awareness has also extended to the Non-Muslims as well. Halal is code of authenticity that a product, service and the production process conforms to the Islamic jurisprudence or Shariah [1]. The term Halal is used as a benchmark for Muslims when performing their daily activities such as eating, drinking or engaging in business transaction. These activities include slaughtering, displaying, storing and preparing food and products related to consumer products [2]. Furthermore, the Halal guideline has been used as a standard in other types of consumer products such as cosmetics, personal care, pharmaceuticals and services such as banking and tourism industry [1].

There are four predictors that motivate consumers to purchase Halal food product, namely safety, religious values, health benefits and exclusiveness [3]. Previous studies also revealed several factors that influence non-Muslim's intention to purchase Halal food products. These factors include attitude, awareness and understanding of the Halal concept, food safety, fair trade and environmentally friendly [4]. Other predictors that may be influencing the acceptance of Halal labeled food product among Muslim consumers in Malaysia [4]. Religiosity, behavioral control, and subjective norm are among the most common factors. The objectives of this study areto identify the crucial factors that influence both Muslim and non-Muslim customers' to purchase Halal certified consumer products in Malaysian anddetermine the most dominant factor that significantly influences the customers' purchase intention. This research ventures into factors that drive consumer intention to buy Halal certified products namely halal awareness, marketing, and religiosity.

As Muslims, consuming Halal product is a necessary obligation and Halal logo plays an important part in enticing Muslim consumer's to buy Halal products [5]. Generally, the Halal logo is sufficient to show that the consumer products meet the Islamic standard [6]. However, there have been cases where certain manufacturers utilize prohibited elements in their products. Thus, Muslim customers need to be very heedful when they buy these products 
[6]. Another case that involves manufacturers is when they failed to follow the requirements set by JAKIM when producing Halal certified consumer products for the market [7].

Besides the Halal logo certified by JAKIM, there are other 'illegal' organizations or non-profit organizations that produce fake Halal logo. Nowadays, customers are easily deluded with fake Halal logos in the market. Halal logo can motivate customers' intention to purchase Halal certified products even when the customers are unaware of the legitimacy of the Halal logo [8]. Cleanliness is also important in producing Halal consumer products. In Islam there are specific principles and guidelines to comply with the Islamic Shariah requirement when producing clean Halal products [9].

Another important issue is the awareness of the international Halal logo from other countries such as China, Thailand, Australia, New Zealand, and the United States of America (USA). Even though JAKIM has launched a portal that listed all authorized Halal logo from other countries, not all consumers take the initiative to review it [10]. As a result consumers became confused or doubtful in their purchases as they were unable to verify the authenticity of the foreign Halal logo.

\subsection{Literature Review}

Halal awareness is the ability of a Muslim to understand what a Halal product actually is. This includes their awareness on how products are being stored, sanitary practices, and transferred in the distribution system. For instance, how well a Muslim is able to separate Halal from non-Halal product during shipment and storage to prevent contamination of these products [1]. Unfortunately, Halal concept has been conventionally constrained only to food or anything related to food when in fact in Islam Halal also covers larger facets of life such as in business and banking industries. Muslims and non-Muslims all over the worldhave become more receptive towards Halal issues. As Muslims, Halal is a prerequisite to all things, methods and process applied and consumption in his or her daily life. In a Muslim country the Halal concept is not limited to only Muslims but must be extended as the law of a country [11]. Generally, many non-Muslims in Muslim countries are exposed to knowledge about Halal among Muslims. However, there is a paucity of studies that include non-Muslim customers in their awareness studies.

Muslims are supposed to know what Halal products are. Failure in recognizing Halal product 
can lead them to inadvertently buying non-Halal products [12]. In addition to the shipment and placement of Halal products during transportation, ingredients used in food products must not originate from the non-Halal sources. Nowadays, many imported products may have non-Halal ingredients like alcohol or gelatin and enzymes because they may be extracted from pork [11].

Whenever a product acquires a Halal certification logo it increases customer's confidence to buy those products. Certification can be defined as a recognition given to a business entity from a relevant authoritative body [7]. In Malaysia, this recognition is granted by JAKIM, a body that developed the Halal logo and enforces the Halal Certification System for all food businesses. Today JAKIM has one of the most distinguished Halal audit systems in the world in producing Halal certification for its clients.

Marketing is fundamental in any business because without an sound marketing strategy a business cannot earn good profits. With marketing a business can attract more customers. Producers need to intensively exploit the marketing communication such as spending advertisement in the conventional print and electronic media to attract more purchases of their Halal products [13].

Apart from marketing communication, packaging can be another marketing strategy that can attract customers to purchase Halal certified consumer products. Packaging, branding, and promotional issue of Halal certified consumer products are also factors that can lure customers to buy Halal products. The function of packaging is to reveal important information and to protect products from damages during the handling process. A product must have the name or brand name of the product, list of ingredients, expired date, Halal certified logo, name and address of the manufacturer and others [14]. Attractive packaging can entice potential customers to examine the Halal products, such as proper colors and pictures on the packaging that can capture customers' attention on Halal products. Previous studies showed that labeling, packaging, product produced media, religiosity, company's image and other certifications can also provide positive impact on consumers' level of confidence on the Halal certification logo [7]. Thus, the Halal logo and relevant information printed on the packaging can influence customers' intention to purchase Halal certified consumer products.

Another element that can entice more customers to purchase Halal certified consumer product 
is through branding [15]. Branding can help customer distinguish Halal product from non-Halal products. A powerful brand can help create an identity for Malaysian Halal products and also able to contrast it from other foreign products [15]. Marketing aspects are vital in any business endeavor.

Religion plays a significant part in shaping a person's attitude [11]. Religion dominates its followers' behavior through various rules and regulations. For example, every Muslim must consume only halal products and use halal services such as the Islamic banking system and Islamic finance.Religiosity is the extent to which people are committed to their religion, reflecting their attitude and behavior in either obeying or violating the religion's rules and regulations [11]. Religion is able to shape a person's thinking and attitude based on the value they uphold [15]. They added that religiosity can also influence both the Muslims and non-Muslims to buy Halal certified consumer product and services. Religiosity can shape Muslim and non-Muslims customers in two areas namely internal (intra-personal) and external (inter-personal) [11]. Internal factors include religious attitude, religious identities, values and beliefs while external factors are the individual's membership in a religious community.

"And eat of the things which Allah has provided for you, lawful and good, but fear Allah in whom you believe." (Al Maaidah: 88).

From the above Quranic verse, Allah stresses to all Muslims to consume food that is wholesome and Halal. Islam provides guidelines that can shape their adherents' lifestyle directly from the Sunnah and the Quran. Sunnah is the lifestyles of Prophet Muhammad originated from the teaching of Quran [10]. These guidelines manifest the concept of 'halal, haram andmakrooh' [4].

Halal means lawful or permissible in Islam. Halal as religious, healthy, organic, environmentally friendly, animal welfare, ethnic and fair trade, and in economy the services or business is conducted in a manner permissible in Islam [4]. Not only what we eat need to be Halal but also the economic sector such as banking and insurance service products must be Halal based on Islamic paradigm namely Shariah-compliant [3]. In Malaysia religiosity is quite a common subject among Muslims. However not many studies include non-Muslims as participants while assessing the level of religiosity in the purchase of Halal consumer 
products.

Any industries or business have one sole concern for survival and that concern is to increase customer by prompting customer's intention to purchase their products or services. Intention is the tendency in people to perform certain behavior or a reflection of future behavior [16]. Intention is demonstrated by a person's disposition to engage in certain behavior [17]. Purchase intention involves customers' behavior on their willingness to buy, use, and their focus on specific brands or products [15]. Another meaning for purchase intention is "what we think we will buy" [18]. Intention is the preliminary process that occurs before the actual purchase, which reflect future behavior [19]. Thus purchase intention can affect the buying decision of the customer.

\section{RESULTS AND DISCUSSION}

\subsection{Reliability analysis}

The reliability test is conducted in order to ensure consistent measurement across time and over the various items in the instrument [20]. The independent variables (HALAL Awareness, Marketing and Religiosity) and dependent variables (customers' intention to purchase HALAL certified consumer products) were tested on Cronbach's Alpha coefficient for inter-item reliability. Items are considered reliable when the Cronbach's Alpha above 0.70 [21]. Finding shows all factors are reliable. Independent variables show the range of Cronbach's Alpha values in between 0.863 to 0.936 . Meanwhile for the Dependent Variable Cronbach's Alpha is 0.939 . Thus, all factors are considered reliable.

\subsection{Correlational analysis}

In order to analyze the relationship between the independent and dependent variables Pearson Correlation Coefficient was applied using the guidelines [22]. The result was analyzed by observing the $r$ value as shown in Table 1 . 
Table 1. Correlation analysis

\begin{tabular}{ccccc}
\hline & HA & MKT & RLG & CI \\
\hline HALAL Awareness (HA) & 1 & & & \\
\hline Marketing (MKT) & $0.831^{* *}$ & 1 & & \\
\hline Religiosity (RLG) & $0.871^{* *}$ & $0.788^{* *}$ & 1 & \\
\hline $\begin{array}{c}\text { Customer's Intention } \\
\text { to Purchase (CI) }\end{array}$ & $0.807^{* *}$ & $0.688^{* *}$ & $0.822^{* *}$ & 1 \\
\hline & & & & \\
\hline
\end{tabular}

$\mathrm{N}=309, * *$ Correlation is significant at the 0.01 level (2- tailed)

The study was used the significant level of 0.01 which represents $99 \%$ level of confidents. The results shows that is a strong significant correlation between Halal awareness and customers' intention to purchase Halal certified consumer products where the r-value is 0.807 $(\mathrm{p}<0.01)$. Therefore, it can be concluded that there is a relationship between halal awareness factor and customers' intention to purchase halal certified consumer products. This result therefore support previous finding that there is also positive relationship between Halal awareness factor and customers' intention to purchase Halal certified consumer products in his study [7].

Correlational test also showed that there is a moderate and significant relationship between marketing and customer's intention to purchase Halal certified consumer products where the $r$-value is $0.688(\mathrm{p}<0.01)$. Therefore, this study concludes there is a positive relationship between marketing factors and customers' intention to purchase halal certified consumer products. This findings therefore supports previous research, that marketing factor has positive relationship with customers' intention to purchase Halal certified consumer products [23].

Based on the correlational testing above there is a strong significant correlation between religiosity and customer's intention to purchase halal certified consumer products where the $r$-value is $0.828(\mathrm{p}<0.01)$. This concludes that religiosity factor and customers' intention to purchase Halal certified consumer products are positively correlated and therefore supports previous studies that there are positive relationship between religiosity and customers' intention to purchase halal certified consumer products [23] [24]. 


\subsection{Multiple Regression analysis}

To answer the research question, the researcher applied multiple regression analysis in order to assess the extent to which Halal awareness, marketing and religiosity influence customers' intention to purchase Halal certified consumer products. Multiple regressions were used to predict the amount of variance explained in the dependent variable against more than one dimension of the independent variables [21]. In identifying which factor that has the most influence on customers' intention to purchase halal certified consumer products, the researcher compared the values of the Standard Coefficient Beta value.

The empirical results are summarized in Table 2. Two factors (HALAL awareness and religiosity) are found to explain $71.7 \%$ of the variance in customers' intention to purchase HALAL certified consumer products $\left(\mathrm{R}^{2}=0.717\right)$. These two factors are also contributed positively and significantly in explaining the variance in customers' intention to purchase HALAL certified consumer products. This can be shown from the results obtained on HALAL awareness $(\beta=0.391, \mathrm{p}<0.01)$ and religiosity $(\beta=0.530, \mathrm{p}<0.01)$. Furthermore, it is discovered that marketing efforts is not significant in explaining the variance in customer' intention to purchase HALAL certified consumer products. The study however revealed that the result of HALAL awareness has a multicollinearity effect with the Religiosity variable. As suggested by Tufféry (2011), the tolerance should be greater than 0.2 and the Variance Inflation Factor (VIF) must be lower than 10 or equal to 10 . The range of tolerance is 0.186 to 0.292 meanwhile for the VIF is 3.430 to 5.365 .

Table 2. Multiple regression analysis 1

\begin{tabular}{cc}
\hline $\mathbf{R}^{\mathbf{2}}$ & 0.717 \\
\hline Adjusted $\mathbf{R}^{\mathbf{2}}$ & 0.714 \\
\hline F Change & 257.641 \\
\hline Significance F Change & 0.000 \\
\hline Durbin-Watson & 1.494 \\
\hline
\end{tabular}

Due to the issue of multicollinearity that existed in the regression, the second Multiple Regression Analysis is conducted and the independent variable HALAL awareness was drop from the analysis. The new result analysis on regression is obtained and summarized in Table 
3. The finding shows only religiosity factor explained $68.8 \%$ of the variance in customers' intention to purchase HALAL certified consumer products $\left(\mathrm{R}^{2}=0.688\right)$. The religiosity factor is also found to contribute positively and significantly in explaining the variance in customers' intention to purchase HALAL certified consumer products $(\beta=0.753, p<0.01)$. Nonetheless, marketing factor $(\beta=.095, \mathrm{p}>0.05)$ has shown a negative sign and insignificant in explaining the variance in customer' intention to purchase HALAL certified consumer products. The removal of HALAL awareness factor in the second multiple regression analysis increase the tolerance for marketing (0.379) and religiosity (0.641). Besides that the VIF value for marketing and religiosity factors are reduced and smaller than 10.Therefore, it is concluded that there is no multicollinearity effect between the two variables.

Table 3. Multiple regression analysis 2

\begin{tabular}{cc}
\hline $\mathbf{R}^{\mathbf{2}}$ & 0.688 \\
\hline Adjusted R $^{\mathbf{2}}$ & 0.686 \\
\hline F Change & 338.142 \\
\hline $\begin{array}{c}\text { Significance } \mathbf{F} \\
\text { Change }\end{array}$ & 0.000 \\
\hline Durbin-Watson & 1.379
\end{tabular}

The result shows that religiosity has the highest influence on customers' intention to purchase Halal certified consumer products. This is confirmed by the $\beta$ value of $0.753(p<0.05)$. This indicates that this variable makes the strongest and unique influence to explain the dependent variable. Based on the multiple regression result,marketing actually has negligible influence on customers 'intention to purchase Halal certified consumer products when viewed together with Halal awareness and religiosity. This is confirmed by the $\beta$ value of -0.055 .

\section{EXPERIMENTAL}

\subsection{Theoretical Framework}

In this study, customers' intention to purchase Halal certified consumer products is the dependent variable that is predicted by three independent variables namely Halal awareness, marketing, and religiosity. Recent study highlighted that the stronger the control customers 
feels about making Halal products purchases, the more likely for them to do so because individual's beliefs in the power of both situational and internal factors facilitate the conduct of the behavior (i.e. intention to purchase Halal certified consumer products) [19]. In addition, several variables that influences consumers purchase intention such as Halal awareness, Halal certification, food quality, promotion, and brand [25]. Nevertheless, only food quality was found to be an insignificant contributor to customers' intention to purchase Halal products.

Brand is another factor that affects customers' intention to purchase Halal products [26]. In addition, brand personality has positive effect on customers' intention to purchase the Halal certified products. There are 5 elements of brand personality; sincerity, competence,excitement, sophistication and ruggedness [15]. Furthermore, brand; price, quality, ingredients, and labeling are significant factors that are positively related to purchase intention of Halal cosmetic product [9]. On the other hand research on perceptions of Halal food product finds that safety, religious values, health, and exclusivity have positive effects on customer's intention of purchasing Halal food [3]. Based on these literatures, the researchers constructed a conceptual framework for this study as shown in Fig. 1.

Independent Variables Dependent Variable

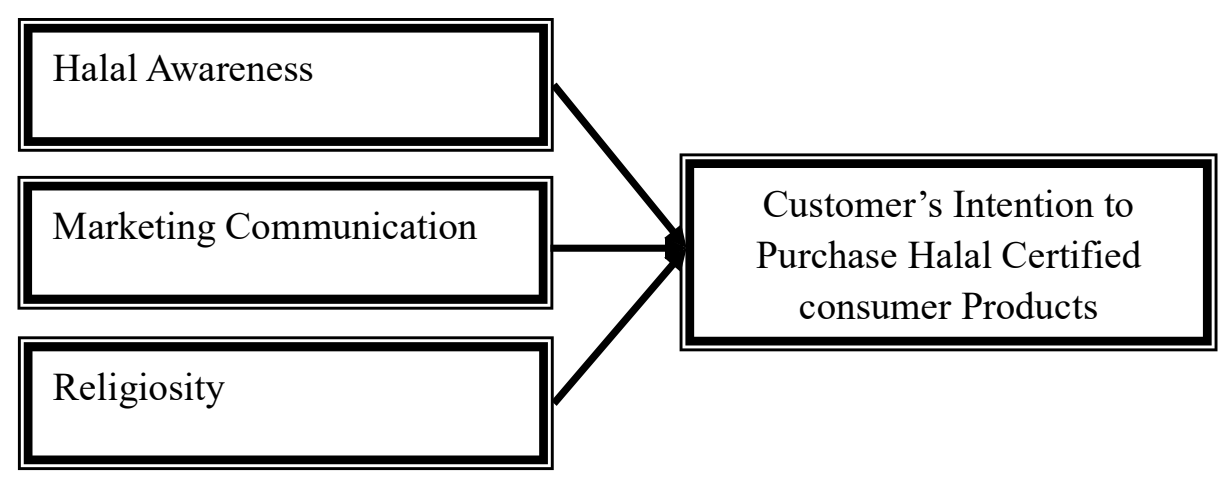

Fig.1. Conceptual framework for factors influencing customers' intention to purchase certified halal consumer products

The study's sample was selected from SABASUN Hypermarket Sdn. Bhd. Kuala Terengganu which Malaysian Muslim and non-Muslim customers. In obtaining the sampling frame, the 
list of total customers was obtained from Customer Service department of the management and only Malaysians were counted.

In selecting population in this study, the number of Muslims and non-Muslim customers at SABASUN Hypermarket Sdn. Bhd. Kuala Terengganu were calculated from April 2015. The total number of customers recorded visiting to SABASUN in April 2015 is 3100 which Malay customers have the highest percentage (79\%). It is followed by Chinese $(15 \%)$ and Indian customers (5\%). The non Malaysian customers only consist of $1 \%$. Nonetheless, the selection of April 2015 is due to the highest number of non-Muslim customers compared to the other months as recorded from the Customer Service Department.

\subsection{Sampling technique and sample size}

For the number of 3100 population, 341 samples should be taken [27]. This is the process of selecting a sufficient number of elements from the population. There is $5 \%$ margin of error, which $95 \%$ of desired confident interval has been obtained. Therefore, this study is choosing the convenience sampling technique. This technique is chosen as there are Muslims and non-Muslims customers at SABASUN Hypermarket Kuala Terengganu.

\subsection{Research Instrument}

The questionnaires were used as a research instrument and it was adopted [28]. Seven (7) Likert answers were provided; (1) extremely disagree, (2) strongly disagree, (3) disagree, (4) uncertain, (5) agree, (6) strongly agree and (7) extremely agree. The Likert answers were chosen as it is sensitive and robust measure. Besides that, it is more likely to reflect a respondent's true subjective evaluation of a usability questionnaire item than a 5 Likert scale [29]. The questionnaires were divided into three (3) sections. There are Section A which is demographic background such as gender, age, status marital, race, religion, highest education level, field of occupation and household income. Section B is about HALAL awareness, marketing and religiosity factors and Section C consists about customers' intention to purchase HALAL certified consumer products.

\subsection{Data Collection Method}

Respondents may normally reluctant to express their views openly in person or in a group since it has been proven that they are more willingly to write. Thus, the questionnaires used as data collection were distributed and collected personally by the researcher. The ample time of 
seven (7) minutes are allocated to the Muslims and non-Muslims customers to complete the questionnaire and the researcher was directly collected all the questionnaires in the same day. A cover letter was also attached together with the questionnaire in purpose to explain the objective and the purpose of the study and also to convince the respondents that their given responses will be kept as confidential and are only used for academic purposes. In the data collection process, 322 out of 341 number of questionnaires were return which equal to $94.4 \%$ return rate.

\section{CONCLUSION}

All the three factors employed in this research were developed from previous studies, whereby the researchers expected that all three variables to have a significant relationships and predictive power in driving customers' intention to purchase Halal consumer product. However, only religiosity was found to have the dominant or sole influence in shaping customers' attitude toward Halal purchases.

Several issues can be highlighted in this research. First is customers' awareness towards Halal products. In Malaysia the majority of the population is Muslim adherents. Presumably, Halal awareness should not be a huge challenge in triggering more purchases of Halal products. Nevertheless, the result showed that an increase in religiosity has corresponded positively and significantly with customers' intention to purchase Halal certified consumer products. However, the correlation does not mean that an increase in religiosity will cause an increase customers' intention to buy more Halal certified consumer products, as shown in the subsequent testing. This study has in-fact demonstrated that Halal awareness is not effective enough to drive the sale of more Halal consumer products. In short, Halal awareness alone will not necessarily improve sales. This brings to another implication and that Halal awareness program installed by the authorities so far has not been really effective. The predictive ability of Halal awareness among Muslims and non-Muslims is arguably uncertain. This means that the Halal awareness programs require serious scrutiny and improvement. In a nutshell the quality of Halal awareness among people in Malaysia requires improvement.

Knowledge of Halal certification through advertising may influence the awareness of young Muslims awareness. Good advertisements provide consumers with the correct information, 
increase knowledge and increase their awareness on HALAL products. In general, advertisements of Halal products should be increased on the media to strengthen the role of advertising in promoting Halal products towards Muslims [30].

This study found positive and significant correlation between marketing and customers' intention to buy Halal certified consumer products. An increase in marketing aspects, however does not necessarily improve customers' attitude when to buy more Halal certified consumer products. This proved that marketing efforts have not been effective to drive more customers to purchase Halal certified consumer products.

This study would like to propose several recommendations. The Malaysian government should provide more campaign on the Halal products. In addition, non-governmental organization also should take serious initiatives to further educate to increase the awareness about Halal products. Halal awareness campaigns such as the one launched by 'JabatanKemajuan Islam Malaysia' (JAKIM) should be increased and initiated by more government agencies [31]. JAKIM should always be up-to-date before awarding the Halal certification. Add more guidelines if the organization wants to apply for the Halal certification logo. It is important to avoid incident such the Secret Recipes case. JAKIM revoked Secret Recipe's halal certificate over hygiene violations and was not due to Haram (forbidden) ingredients in its food products [32].

To increase the credibility of Halal certification logo JAKIM also should conduct more rigorous auditing and inspections, including an assessment of ingredients, processing methods, equipment used including laboratory testing by Certification Procedures Manual Standard and Procedure. For example the Cadbury case where certain chocolate products were found tainted with porcine DNA. After thorough investigation The Islamic Development Department (i.e. JAKIM) reiterated that Cadbury chocolates, are free from porcine DNA and therefore Halal to be consumed [33].

Above all, parents should play an important role in educating their children about Halal guidelines and certification. The family institution needs to be educated on the importance of consuming Halal food. The guidelines include reminding the wife to prepare Halal food, reminding the husband not to be involved in "Haram" acts such as corruption and gambling as well as monitoring the food the children eats like junk foods. Parents should also teach their children to look for the Halal logo every single time they buy ingredients and should also stay 
away from restaurants or eateries that are highly doubtful in its Halal or Haram classification [34].

In order to increase the credibility of the study in this area, it is recommended that future research include other factors that can also influence customers' intention to purchase Halal certified consumer products. Conducting moderating test of certain contextual or demographic variables can help researchers assess how factor shaping customer intention to purchase Halal certified product differs across various environments setting in the real world.

\section{ACKNOWLEDGEMENTS}

We would like to express our gratitude to the top management, research, and publication department of UniversitiTeknologi MARA, Terengganu for the educational support towards the accomplishement of this research.

\section{REFERENCES}

[1] Ab TalibMS, Mohd JohanMR. Issues in halal packaging: A conceptual paper. International Business and Management,2012, 5(2):94-98

[2] ShafieS, OthmanMN.Halal certification: An international marketing issues and challenges. In Proceedings of the International IFSAM VIIIth World Congress,2006, pp. 28-30.

[3] Widodo T.The influence of muslim consumer's perception toward halal food product on attitude and purchase intention at retail stores. Inovbiz,2013, 1(1):1-18

[4] RezaiG. Consumers' confidence in halal labeled manufactured food in Malaysia. PhD Thesis, Universiti Putra Malaysia, 2008

[5] OmarKM, MatNKN. ImhemedGA, and AliFMA. The direct effects of halal product actual purchase antecedents among the international Muslim consumers. American Journal of Economics, 2012, 87-92

[6] DaliN, SulaimanS, SamadAA, IsmailN, and AlwiSH.Halal products from the consumers perception. An online survey. In Proceedings of the Islamic Entrepreurship Conference, 2007, pp. 1-12

[7] MasnonoA.Factors influencing the muslim consumer's level of confidence on Halal logo issued by Jakim: An empirical study. PhD Thesis, Universiti Sains Malaysia, 2005 
[8] Abdur RM, Nosheen CS. Religiosity and muslim consumers' decision-making process in a non-Muslim society. Journal of Islamic marketing,2013, 4(2):198-217

[9] HussinSR, HashimH, RajaYusofRN, AliasNN.Relationship between product factors, advertising, and purchase intention of halal cosmetic. Pertanika Journal of Social Sciences \& Humanities, 2013, 21, 85-100

[10] TiemanM, Che GhazaliM.Principles in halal purchasing. Journal of Islamic Marketing,2013, 4(3):281-293

[11] ArshiaM, ButtMM.Intention to choose Halal products: The role of religiosity. Journal of Islamic Marketing, 2012, 3(2):108-120

[12] SirajuddinMDM, SahriM, KhalidMM,Yaakob, MAZ, and HarunHMF. Introducing halalan tayyiban concept in global industry practices: An innovative attempt. In International Proceedings of Economics Development and Research,2013, 66,pp. 44

[13] Abdul AzizY, ChokNV. The role of halal awareness and halal certification in influencing non-muslims' purchase intention. In Proceedings of the $3^{\text {rd }}$ International Conference on Business And Economic Research, 2012, pp. 1819-1830

[14] ZannierahSM, Hall, CM, and BallantinePW.Restaurant manager and halal certification in Malaysia. Journal of Foodservice Business Research,2012, 15(2):195-214

[15] BorzooeiM, AsgariM.Halal branding and purchase intention: A brand personality appeal perspective. International Journal of Business and Management Invention, 2013, 2(8): 23-27

[16] OmarKM, MatNKN, ImhemedGA, and AliFMA. The direct effects of halal product actual purchase antecedents among the international Muslim consumers. American Journal of Economics,2012, 87-92

[17] Al-NahdiBB, MohammedTS.Intention to patronage halal restaurants among Malaysian muslims: An issue of halal perception. PhD Thesis, Universiti Sains Malaysia,2008

[18] TarkiainenA, SundqvistS.Subjective norms, attitudes and intentions of Finnish consumers in buying organic food. British Food Journal,2005, 107(11):808-822

[19] Afendi N A, Azizan F L, and Darami A I.Determinants of halal purchase intention: Case in Perlis. International Journal of Business and Social Research,2014, 4(5):118-123

[20] TabachnickBG, FidelLS. Using multivariate statistics. 4th.ed. USA: Allyn \& Bacon, 2001

[21] SekaranU.Research methods for business: A skill building approach.New Jersey: John 
Wiley \& Sons, 2006

[22] CohenJ.Statistical power analysis. Current Directions in Psychological Science,1992, 1(3):98-101

[23] KordnaeijA, AskaripoorH, and BakhshizadehA.Studying affecting factors on customers' attitude toward products with halal brand: Case study in Kuala Lumpur, Malaysia. International Research Journal of Applied and Basic Sciences,2013, 4(10): 3138-3145

[24] SialaH.Religious influences on consumers' high-involvement purchasing decisions. Journal of Services Marketing,2013, 27(7):579-589

[25] Abdul AzizY, ChokNV. The role of halal awareness and halal certification in influencing non-muslims' purchase intention. In Proceedings of the $3^{\text {rd }}$ International Conference on Business And Economic Research, 2012,pp. 1819-1830

[26] HusainR, GhaniIA, MohammadA, and MehadS. Current practices among halal cosmetics manufacturers in Malaysia. Journal of Statistical Modeling and Analytic,2012, 3(1):46-51

[27] KrejcieRV, MorganDW.Determining sample size for research activities. Educational and Psychological Measurement, 1970, 30, 607-610

[28] ShaariJAN, Mohd ArifinNS. Dimension of halal purchase intention: A preliminary study. In American Business Research Conference, 2009

[29] FinstadK.Response interpolation and scale sensitivity: Evidence against 5-point scales. Journal of Usability Studies,2010, 5(3):104-110

[30] SaabarSS, IbrahimSB. The knowledge of halal and advertising influence on young muslims awareness. In Proceedings of the International Economics Development and Research, 2014, 73,pp. 36.

[31] Jabatan Kemajuan Islam Malaysia.Launching of the halal awareness campaign, 2012

[32] The Straits Times Online.Malaysia revokes halal certificate of restaurant chain Secret Recipe due to 'cleanliness issues', 2015

[33] TambooTKL.Cadbury chocolates are Halal, Jakim reiterates, 2014

[34] Hana, R.Importance of consuming halal food in the family, 2012

\section{How to cite this article:}

Zakaria Z, Abdul Majid M D, Ahmad Z, Jusoh Z, Zakaria N Z. Influence of halal certification on customers' purchase intention. J. Fundam. Appl. Sci., 2017, 9(5S), 772-787. 